\title{
THE EFFECT OF THERMAL PROCESSING ON THE PROTEIN QUALITY OF MONODORA MYRISTICA (GAERTN.) DUNAL SEEDS
}

\author{
Anna N. Agiriga ${ }^{1,2 \bowtie}$, Siwela Muthulisi ${ }^{1}$ \\ ${ }^{1}$ School of Agricultural, Earth and Environmental Sciences, University of KwaZulu-Natal \\ Pietermaritzburg 3201, South Africa \\ 2Department of Food Science and Technology, Federal University Oye-Ekiti \\ Ekiti State, Nigeria
}

\begin{abstract}
Background. Monodora myristica (Gaertn.) Dunal is a useful but underutilised tropical tree of the Annonaceae or custard apple family of flowering plants which is rich in proteins. The objective of this study was to evaluate the effect of thermal processing on the protein quality of Monodora myristica (Gaertn.) Dunal seeds. Materials and methods. Raw, boiled (10, 20, $30 \mathrm{~min})$ and roasted (10, 20, $30 \mathrm{~min})$ Monodora myristica seeds were defatted, and the effect of heat treatment on their crude protein, amino acid composition/concentration and protein quality parameters was investigated.

Results. The results showed that crude protein was significantly reduced by heat treatment and ranged between 19.92-23.32\%. Essential amino acids of the samples ranged from 26.34-34.06\%. Glutamic acid $(14.58 \mathrm{~g} / 100 \mathrm{~g})$, aspartic acid $(9.18 \mathrm{~g} / 100 \mathrm{~g})$, leucine $(7.76 \mathrm{~g} / 100 \mathrm{~g})$ and lysine $(6.91 \mathrm{~g} / 100 \mathrm{~g})$ were the most predominant amino acids, while methionine + cysteine was the first limiting amino acid. There were some increases in some of the amino acids in the roasted samples. For instance, lysine was increased by $3.3 \%$ and arginine by $6.9 \%$. The predicted protein efficiency ratio at all levels of processing was higher than 1.50 , below which a protein is taken to be of poor quality. The calculated biological value ranged from $70.7 \%$ to $77.7 \%$. Based on The Provisional Amino Acid (Egg) Scoring Pattern, the percentage adequacy of most essential amino acids in the samples was high.

Conclusion. Despite the decrease in most amino acid contents by cooking, the plant food has the potential to provide high quality protein which can be exploited to enhance protein quality in human nutrition and performance in sports.
\end{abstract}

Keywords: Monodora myristica, amino acid composition, protein efficiency ratio, amino acid score

\section{INTRODUCTION}

Animal protein is still far more expensive than its plant counterpart for most inhabitants of developing countries and for years this has aroused rigorous research on underutilized plant proteins that can be used as a protein source in food ingredients and functional foods formulation (Chavan et al., 2001; Sreerama et al., 2010). Monodora myristica (Gaertn.) Dunal is a useful but underutilised tropical tree of

This research was carried out with financial support from the College of Agriculture, Engineering and Science, University of KwaZulu-Natal, South Africa. 
the Annonaceae or custard apple family of flowering plants (Burubai et al., 2009; Ojiako et al., 2010). Its economic importance lies in the edibility of its oil-rich seeds which are consumed in Sub-Saharan Africa (Akinwunmi and Oyedapo, 2013; Enabule et al., 2014). The aromatic seeds are antiemetic, aperient, stimulant, stomachic tonic and they are added to medicines to impart stimulating properties (Iwu et al., 1987; Udeala, 2000; Weiss, 2002). The seed is rich in minerals and proteins (Burubai et al., 2009; Ekeanyanwu et al., 2010). This makes it a potential plant protein which can supplement the monotonous starchy staples being consumed by many in developing countries with little or no alternatives.

Amino acid composition is the most important factor in defining food protein quality (Olaofe et al., 1994; Onyeike et al., 2005; Severin and Wen-Shui, 2006). Most processing methods, especially heat processing, have detrimental effects on nutrients. Monodora myristica seeds are processed locally (in the regions of Sub-Saharan Africa) using various indigenous knowledge-based processing techniques like boiling, roasting and frying for varying lengths of time. Tuleum et al. (2009) reported that an increase in boiling time significantly decreased the crude protein and most essential amino acid contents of $\mathrm{Mucu}$ na utilis. Earlier, Pisarikova et al. (2005) reported that heat processing can cause damage to essential amino acids resulting in decreased contents or conversion into a racemic mixture. Other researchers reported either increased or decreased levels of amino acids after processing (Adeyeye, 2010; Ismail et al., 2004; Nuray et al., 2010). Ojiako et al. (2010) investigated the effect of blanching $(5 \mathrm{~min})$ and boiling (undisclosed time) on the protein content and amino acid composition of Monodora myristica seeds. Adeolu et al. (2015) assessed the amino acid composition of Monodora myristica seeds. Unfortunately, there is a lack of information on the impacts of different processing methods (at defined time intervals) on the amino acid composition/concentration and other protein quality parameters of Monodora myristica seeds. This study was therefore undertaken to investigate the effect of different cooking methods (boiling and roasting) and cooking times (10,20 and $30 \mathrm{~min})$ on the amino acid composition/concentration, predicted protein efficiency ratio (P-PER), predicted biological value (PBV) and amino acid score of Monodora myristica seed flour. This research is expected to provide information on the possible uses of Monodora myristica proteins as potential functional ingredients and food supplements.

\section{MATERIALS AND METHODS}

Reagents and chemicals. Unless otherwise stated, all the chemicals/reagents used were of analytical grade from Sigma-Aldrich Co., Ltd (Steinheim, Germany).

Sample. Monodora myristica seeds were purchased from a local market, in Ado-Ekiti, Ekiti State, Nigeria.

Sample preparation. The seeds were cleaned and extraneous materials like dry leaves and stones removed. Samples were divided into seven portions and prepared using the method of Mbah et al. (2012) with slight modification. The first portion was raw, and it served as the control. The second, third and fourth portions were boiled $\left(100^{\circ} \mathrm{C}\right)$ in a pot of tap water in a ratio of $1: 3$ (weights of the seeds to volume of water) for varying times: 10, 20 and $30 \mathrm{~min}$. After boiling, the seeds were oven dried at $100^{\circ} \mathrm{C}$ for $5 \mathrm{~h}$, dehulled and milled into fine flour. The remaining fifth, sixth and seventh portions were roasted $\left(120^{\circ} \mathrm{C}\right)$ for different times (10, 20 and $30 \mathrm{~min}$ ), dehulled and milled into fine flour. The control seeds were dehulled and milled without any thermal processing. Flour samples were defatted for $4 \mathrm{~h}$ using a Buchi 810 Soxhlet Fat Extractor (Flawil, Switzerland) and packaged in labelled polythene bags (CO: raw flour; B10, B20, B30: flour from seeds boiled for 10, 20 and 30 min respectively; R10, R20, R30: flour samples from seeds roasted for 10, 20 and 30 min respectively). The packaged flour samples were stored in a cool $\left( \pm 4^{\circ} \mathrm{C}\right)$ dry place until required for analysis.

\section{Crude protein determination}

Nitrogen content of the flour samples was determined using the micro-Kjeldahl method. Crude protein content was estimated by multiplying $\% \mathrm{~N}$ by a factor, 6.25 (Chukwuma et al., 2016). All analyses were carried out in duplicate. 


\section{Determination of amino acid composition}

Amino acid composition of the flour samples was determined using methods described by Adigun et al. (2015). Defatted flour samples were dried to a constant weight, hydrolysed, evaporated in a rotary evaporator and loaded into the Technicon ${ }^{\circledR}$ Sequential Multisample Amino Acid Analyzer (Technicon Instruments Corporation, New York, USA). For the hydrolysis, $50 \mathrm{mg}$ of the defatted samples were weighed into a glass ampoule, $7 \mathrm{ml}$ of $6 \mathrm{~N} \mathrm{HCl}$ was added and oxygen was expelled by passing nitrogen into the ampoule (this was to avoid possible oxidation of some amino acids during hydrolysis). The glass ampoule was then sealed with a Bunsen burner flame and put in an oven preset at $105^{\circ} \mathrm{C} \pm 5^{\circ} \mathrm{C}$ for 22 hours to effect hydrolysis. The ampoule was allowed to cool before it was broken open at the tip and the contents were filtered to remove the humins. The filtrate was then evaporated to dryness at $40^{\circ} \mathrm{C}$ under vacuum in a rotary evaporator. The residue was dissolved with $5 \mathrm{ml}$ of acetate buffer (pH 2.0) and stored in plastic specimen bottles, which were kept in a deep freezer. The hydrolysate $(10 \mathrm{mi}-$ crolitre) was then loaded into the Technicon ${ }^{\circledR}$ Sequential Multisample Amino Acid Analyzer. The period of one analysis was $75 \mathrm{~min}$. The amino acids present in the samples were identified by matching their peak retention time in the chromatogram with the peaks of the standard mixture of amino acids, with norleucine as an internal standard.

The amount of each amino acid present in the different samples was calculated in $\mathrm{g} / 16 \mathrm{~g} \mathrm{~N}$ or $\mathrm{g} / 100 \mathrm{~g}$ protein using the formula below as described by Ekeanyanwu (2013).

$$
\begin{gathered}
\text { Concentration, g/100 g protein }= \\
=\mathrm{NH} \times W @ \mathrm{NH} / 2 \times S_{\text {std }} \times C
\end{gathered}
$$

where:

$$
\begin{aligned}
\mathrm{C} \quad- & \text { dilution } \times 16, \\
\text { sample }- & W_{t}, \mathrm{~g} \times N \% \times 10 \times \text { vol. loaded } \times \mathrm{NH} \times \\
& W(\mathrm{nleu}), \\
\mathrm{NH} \quad- & \text { net height, } \\
W \quad- & \text { width } @ \text { half height (nleu }- \text { norleucine }) .
\end{aligned}
$$

\section{Protein quality evaluation}

Amino acid score was calculated using the $\mathrm{FAO} / \mathrm{WHO}$ (1973) formula as adapted by Onyeike et al. (2005):

$$
\begin{gathered}
\text { Amino acid } \\
\text { score }
\end{gathered}=\frac{\begin{array}{c}
\text { amount of amino acid } \\
\text { in sample protein, } \mathrm{mg} / \mathrm{g}
\end{array}}{\begin{array}{c}
\text { amount of amino acid } \\
\text { in reference protein, } \mathrm{mg} / \mathrm{g}
\end{array}} \times 100
$$

The total amino acid (TAA), total essential amino acid (TEAA), TEAA as percentage of TAA (\% TEAA), total acidic amino acid (TAAA), total basic amino acid (TBAA), total sulphur amino acid (TSAA), percentage cysteine in TSAA (\% Cys/TSAA), total aromatic amino acid (TArAA), Leu/Ile ratio etc. were estimated from the amino acid profile. The predicted protein efficiency ratio (P-PER) was calculated from the amino acid composition using one of the equations derived by Alsmeyer et al. (1974), as adapted by Adeyeye (2010):

$$
\text { P-PER }=-0.468+0.454(\mathrm{Leu})-0.105(\mathrm{Tyr})
$$

\section{Computation of predicted biological value (PBV)}

Predicted biological value (PBV) was calculated following the equation of Oser (1959) as adapted by Adeolu et al. (2015):

$$
\mathrm{PBV}=49.09+10.53(\mathrm{PER})
$$

where:

PER - protein efficiency ratio.

\section{Statistical analysis}

Statistical Package for Social Sciences (SPSS - version 20) was used to obtain mean and standard deviation. Analysis of variance (ANOVA) was done and judged for significance at $p \leq 0.05$. Means were separated using Duncan's Multiple Range Test (DMRT).

\section{RESULTS AND DISCUSSION}

\section{Essential and non-essential amino acid composition}

The essential and non-essential amino acid compositions ( $\mathrm{g} / 100 \mathrm{~g}$ crude protein) of raw and cooked Monodora myristica seed flour are shown in Table 1 and compared with those of other plant foods in Table 2. The samples at all levels of processing contained the amino acids found naturally in plant protein. From Table 1, Glutamic acid was the most abundant nonessential amino acid in the samples analysed, with values ranging from 12.13 to $14.58 \mathrm{~g} / 100 \mathrm{~g}$ crude protein 
Agiriga, A. N., Muthulisi, S. (2018). The effect of thermal processing on the protein quality of Monodora myristica (Gaertn.) Dunal seeds. Acta Sci. Pol. Technol. Aliment., 17(4), 321-333. http://dx.doi.org/10.17306/J.AFS.2018.0588

Table 1. The effects of thermal processing on the amino acid composition of Monodora myristica seeds flour, g/100 g crude protein

\begin{tabular}{|c|c|c|c|c|c|c|c|}
\hline \multirow[b]{2}{*}{ Parameters } & \multirow[b]{2}{*}{ Raw } & \multicolumn{3}{|c|}{ Roasted } & \multicolumn{3}{|c|}{ Boiled } \\
\hline & & $\begin{array}{l}10 \text { mins } \\
(\mathrm{R} 10)\end{array}$ & $\begin{array}{l}20 \text { mins } \\
\text { (R20) }\end{array}$ & $\begin{array}{c}30 \text { mins } \\
\text { (R30) }\end{array}$ & $\begin{array}{l}10 \text { mins } \\
\text { (B10) }\end{array}$ & $\begin{array}{l}20 \text { mins } \\
\text { (B20) }\end{array}$ & $\begin{array}{c}30 \text { mins } \\
\text { (B30) }\end{array}$ \\
\hline Lysine* & $6.68^{\mathrm{b}}$ & $6.75^{\mathrm{b}}$ & $6.87^{\mathrm{a}}$ & $6.91^{\mathrm{a}}$ & $5.86^{\mathrm{c}}$ & $5.55^{\mathrm{d}}$ & $5.37^{\mathrm{e}}$ \\
\hline Histidine* & $3.01^{\mathrm{a}}$ & $2.76^{\mathrm{b}}$ & $2.75^{\mathrm{bc}}$ & $2.68^{\mathrm{cd}}$ & $2.64^{\mathrm{de}}$ & $2.57^{\mathrm{e}}$ & $2.33^{\mathrm{f}}$ \\
\hline Isoleucine* & $3.62^{\mathrm{a}}$ & $3.55^{\mathrm{b}}$ & $3.48^{\mathrm{c}}$ & $3.32^{\mathrm{d}}$ & $3.18^{\mathrm{e}}$ & $3.01^{\mathrm{f}}$ & $2.78^{\mathrm{g}}$ \\
\hline Leucine* & $7.76^{\mathrm{a}}$ & $7.62^{\mathrm{b}}$ & $7.06^{\mathrm{c}}$ & $7.02^{\mathrm{c}}$ & $6.80^{\mathrm{d}}$ & $6.41^{\mathrm{e}}$ & $6.13^{\mathrm{f}}$ \\
\hline Threonine* & $3.16^{\mathrm{a}}$ & $2.90^{\mathrm{b}}$ & $2.85^{\mathrm{bc}}$ & $2.77^{\mathrm{cd}}$ & $2.77^{\mathrm{cd}}$ & $2.69^{d}$ & $2.45^{\mathrm{e}}$ \\
\hline Phenylalanine* & $4.18^{\mathrm{a}}$ & $3.94^{\mathrm{b}}$ & $3.81^{\mathrm{c}}$ & $3.78^{c}$ & $3.66^{\mathrm{d}}$ & $3.47^{\mathrm{e}}$ & $3.35^{\mathrm{f}}$ \\
\hline Tyrosine & $3.18^{\mathrm{a}}$ & $3.15^{\mathrm{a}}$ & $2.88^{\mathrm{b}}$ & $2.65^{\mathrm{e}}$ & $2.79^{c}$ & $2.73^{\mathrm{d}}$ & $2.52^{\mathrm{f}}$ \\
\hline Methionine* & $1.27^{\mathrm{a}}$ & $1.25^{\mathrm{a}}$ & $1.16^{\mathrm{b}}$ & $0.95^{\mathrm{d}}$ & $1.11^{\mathrm{c}}$ & $0.78^{\mathrm{e}}$ & $0.49^{\mathrm{g}}$ \\
\hline Cysteine & $1.17^{\mathrm{a}}$ & $1.09^{\mathrm{b}}$ & $0.97^{\mathrm{d}}$ & $0.78^{\mathrm{f}}$ & $1.03^{\mathrm{c}}$ & $0.89^{\mathrm{e}}$ & $0.72^{\mathrm{g}}$ \\
\hline Valine* & $4.38^{\mathrm{a}}$ & $4.32^{\mathrm{a}}$ & $4.18^{\mathrm{b}}$ & $3.99^{\mathrm{c}}$ & $3.84^{\mathrm{d}}$ & $3.65 \mathrm{e}$ & $3.44^{\mathrm{f}}$ \\
\hline Aspartic acid & $9.18^{\mathrm{a}}$ & $8.77^{\mathrm{b}}$ & $8.42^{\mathrm{c}}$ & $8.31^{\mathrm{d}}$ & $8.05^{\mathrm{e}}$ & $7.74^{\mathrm{f}}$ & $7.17^{g}$ \\
\hline Arginine & $5.98^{\mathrm{c}}$ & $6.04^{\mathrm{c}}$ & $6.19^{\mathrm{b}}$ & $6.42^{\mathrm{a}}$ & $5.24^{\mathrm{d}}$ & $4.98^{\mathrm{e}}$ & $4.04^{\mathrm{f}}$ \\
\hline Alanine & $3.88^{\mathrm{c}}$ & $3.93^{b c}$ & $3.97^{b}$ & $4.04^{\mathrm{a}}$ & $3.40^{\mathrm{d}}$ & $3.39^{\mathrm{d}}$ & $3.39^{\mathrm{d}}$ \\
\hline Glycine & $4.08^{\mathrm{c}}$ & $4.14^{\mathrm{bc}}$ & $4.18^{\mathrm{b}}$ & $4.44^{\mathrm{a}}$ & $3.58^{\mathrm{d}}$ & $3.57^{\mathrm{d}}$ & $3.49^{\mathrm{e}}$ \\
\hline Proline & $4.21^{\mathrm{a}}$ & $3.86^{\mathrm{b}}$ & $3.83^{\mathrm{b}}$ & $2.51^{\mathrm{e}}$ & $3.69^{c}$ & $2.98^{\mathrm{d}}$ & $1.59^{\mathrm{f}}$ \\
\hline Serine & $3.50^{\mathrm{a}}$ & $3.47^{\mathrm{a}}$ & $3.21^{\mathrm{b}}$ & $3.17^{\mathrm{b}}$ & $3.06^{\mathrm{c}}$ & $3.03^{\mathrm{cd}}$ & $2.99^{\mathrm{e}}$ \\
\hline Glutamic acid & $14.58^{\mathrm{a}}$ & $14.50^{\mathrm{b}}$ & $14.38^{\mathrm{c}}$ & $13.70^{\mathrm{d}}$ & $12.78^{\mathrm{e}}$ & $12.40^{\mathrm{f}}$ & $12.13^{\mathrm{g}}$ \\
\hline Crude protein & $23.32^{\mathrm{a}}$ & $21.23^{\mathrm{b}}$ & $21.11^{\mathrm{b}}$ & $21.40^{\mathrm{b}}$ & $20.42^{c}$ & $20.44^{\mathrm{c}}$ & $19.92^{\mathrm{d}}$ \\
\hline
\end{tabular}

*Essential amino acids; means along the row with the same superscripts are not significantly different at $P>0.05$.

followed by aspartic acid which ranged from 7.17 to $9.18 \mathrm{~g} / 100 \mathrm{~g}$ crude protein. Both amino acids are acidic amino acids. Similar observations of other plant proteins have previously been reported (Ajibola et al., 2016; Fagbemi, 2009). Adeyeye (2010) and FAO (1982), reporting on groundnut seeds and soybeans respectively (Table 2) also showed Glutamic and Aspartic acid as the most abundant amino acids. El-Mahdy and El-Sebaiy (1985) reported that high concentrations of Glutamic and Aspartic acid were normal for most seeds.

The high level of Aspartic acid is of importance as it is a precursor of such amino acids as
Asparagine, Threonine and Lysine (Alozie et al., 2009). The lowest value for non-essential amino acids occurred in Cysteine $(0.72 \mathrm{~g} / 100 \mathrm{~g})$ followed by Proline $(1.59 \mathrm{~g} / 100 \mathrm{~g})$. Leucine had the highest value (7.76 g/100 g crude protein) for essential amino acid in all the samples, followed by Lysine $(6.91 \mathrm{~g} / 100 \mathrm{~g}$ crude protein; Table 1). The concentration of Leucine in the samples (6.13-7.76 g/100 g crude protein) is higher than values obtained for spices like pepper, ginger, onion and tomatoes with values of 5.08, $5.66,4.09$ and $3.24 \mathrm{~g} / 100 \mathrm{~g}$ crude protein respectively (Aremu et al., 2011) but slightly lower than values obtained for garlic $8.13 \mathrm{~g} / 100 \mathrm{~g}$ (Aremu et al., 2011). 
Agiriga, A. N., Muthulisi, S. (2018). The effect of thermal processing on the protein quality of Monodora myristica (Gaertn.) Dunal seeds. Acta Sci. Pol. Technol. Aliment., 17(4), 321-333. http://dx.doi.org/10.17306/J.AFS.2018.0588

Table 2. Amino acid composition of raw and cooked M. myristica seed flours compared with those of some plant foods, $\mathrm{g} / 100 \mathrm{~g}$

\begin{tabular}{|c|c|c|c|c|c|c|c|c|c|c|c|}
\hline $\begin{array}{l}\text { Amino } \\
\text { acid }\end{array}$ & Raw & $\mathrm{R} 10$ & $\mathrm{R} 20$ & $\mathrm{R} 30$ & $\mathrm{~B} 10$ & B20 & B30 & Soy bean & Cashew nut & $\begin{array}{l}\text { Groundnut } \\
\text { seeds }\end{array}$ & Wheat \\
\hline Lysine & 6.68 & 6.75 & 6.87 & 6.91 & 5.86 & 5.55 & 5.37 & 6.38 & 3.20 & 3.71 & 2.56 \\
\hline Histidine & 3.01 & 2.76 & 2.75 & 2.68 & 2.64 & 2.57 & 2.33 & 2.53 & 2.40 & 2.20 & 2.56 \\
\hline Isoleucine & 3.62 & 3.55 & 3.48 & 3.32 & 3.18 & 3.01 & 2.78 & 4.54 & 4.00 & 3.64 & 3.37 \\
\hline Leucine & 7.76 & 7.62 & 7.06 & 7.02 & 6.80 & 6.41 & 6.13 & 7.78 & 8.90 & 7.59 & 6.31 \\
\hline Threonine & 3.16 & 2.90 & 2.85 & 2.77 & 2.77 & 2.69 & 2.45 & 3.86 & $2 . .50$ & 2.82 & 2.62 \\
\hline Phenylalanine & 4.18 & 3.94 & 3.81 & 3.78 & 3.66 & 3.47 & 3.35 & 4.94 & 4.10 & 4.83 & 3.95 \\
\hline Tyrosine & 3.18 & 3.15 & 2.88 & 2.65 & 2.79 & 2.73 & 2.52 & 3.14 & 3.30 & 3.27 & 2.59 \\
\hline Methionine & 1.27 & 1.25 & 1.16 & 0.95 & 1.11 & 0.78 & 0.49 & 1.24 & 2.0 & 0.94 & 1.63 \\
\hline Cysteine & 1.17 & 1.09 & 0.97 & 0.78 & 1.03 & 0.89 & 0.72 & 1.33 & 0.30 & 1.39 & 2.18 \\
\hline Valine & 4.38 & 4.32 & 4.18 & 3.99 & 3.84 & 3.65 & 3.44 & 4.80 & 3.70 & 4.41 & 4.22 \\
\hline Aspartic acid & 9.18 & 8.77 & 8.42 & 8.31 & 8.05 & 7.74 & 7.17 & 11.7 & 5.70 & 9.41 & 4.95 \\
\hline Arginine & 5.98 & 6.04 & 6.19 & 6.42 & 5.24 & 4.98 & 4.04 & 7.23 & 4.40 & 5.78 & 4.86 \\
\hline Alanine & 3.88 & 3.93 & 3.97 & 4.04 & 3.40 & 3.39 & 3.39 & 4.26 & 3.50 & 3.79 & 3.37 \\
\hline Glycine & 4.08 & 4.14 & 4.18 & 4.44 & 3.58 & 3.57 & 3.49 & 4.18 & 3.0 & 3.66 & 3.86 \\
\hline Proline & 4.21 & 3.86 & 3.83 & 2.51 & 3.69 & 2.98 & 1.59 & 5.49 & 4.10 & 3.54 & 8.99 \\
\hline Serine & 3.50 & 3.47 & 3.21 & 3.17 & 3.06 & 3.03 & 2.99 & 5.12 & 3.70 & 3.19 & 3.92 \\
\hline Glutamic acid & 14.6 & 14.5 & 14.4 & 13.7 & 12.8 & 12.4 & 12.1 & 18.7 & 19.1 & 14.6 & 28.6 \\
\hline TAA & - & - & - & - & - & - & - & 97.2 & 75.80 & 78.80 & 90.20 \\
\hline TEAA & - & - & - & - & - & & - & 43.3 & 33.20 & 35.90 & 31.70 \\
\hline$\%$ TEAA & - & - & - & - & - & & - & 44.6 & 43.80 & 45.60 & 31.10 \\
\hline Reference & PS & PS & PS & PS & PS & PS & PS & $\begin{array}{l}\text { FAO } \\
(1982)\end{array}$ & $\begin{array}{l}\text { Aremu } \\
\text { et al. } \\
(2006 a)\end{array}$ & $\begin{array}{l}\text { Adeyeye } \\
(2010)\end{array}$ & $\begin{array}{l}\text { Khan } \\
\text { and Eggum } \\
(1997)\end{array}$ \\
\hline
\end{tabular}

PS - present study.

This concentration of Leucine in Monodora myristica is in agreement with the observations made earlier by some researchers (Aremu et al., 2006b; 2010; Olaofe et al., 2008) that Leucine is the most concentrated essential amino acid in Nigerian plant products. Furthermore, the abundance of Leucine in the test samples is of nutritional significance as together with Valine (3.44-4.38 g/100 g protein) and Isoleucine (2.78$3.62 \mathrm{~g} / 100 \mathrm{~g}$ protein) it constitutes the branched-chain amino acids (BCAAs). The branched-chain amino acids are found in high concentrations primarily in the skeletal muscle tissue. While Isoleucine serves mainly as an antioxidant, Leucine and Valine stimulate protein synthesis, suppress protein catabolism and serve as important fuel sources for skeletal muscle during periods of extreme exertion such as exercise (Blomstrand et al., 2006; Combaret et al., 2005; Shimomura et al., 2004). 


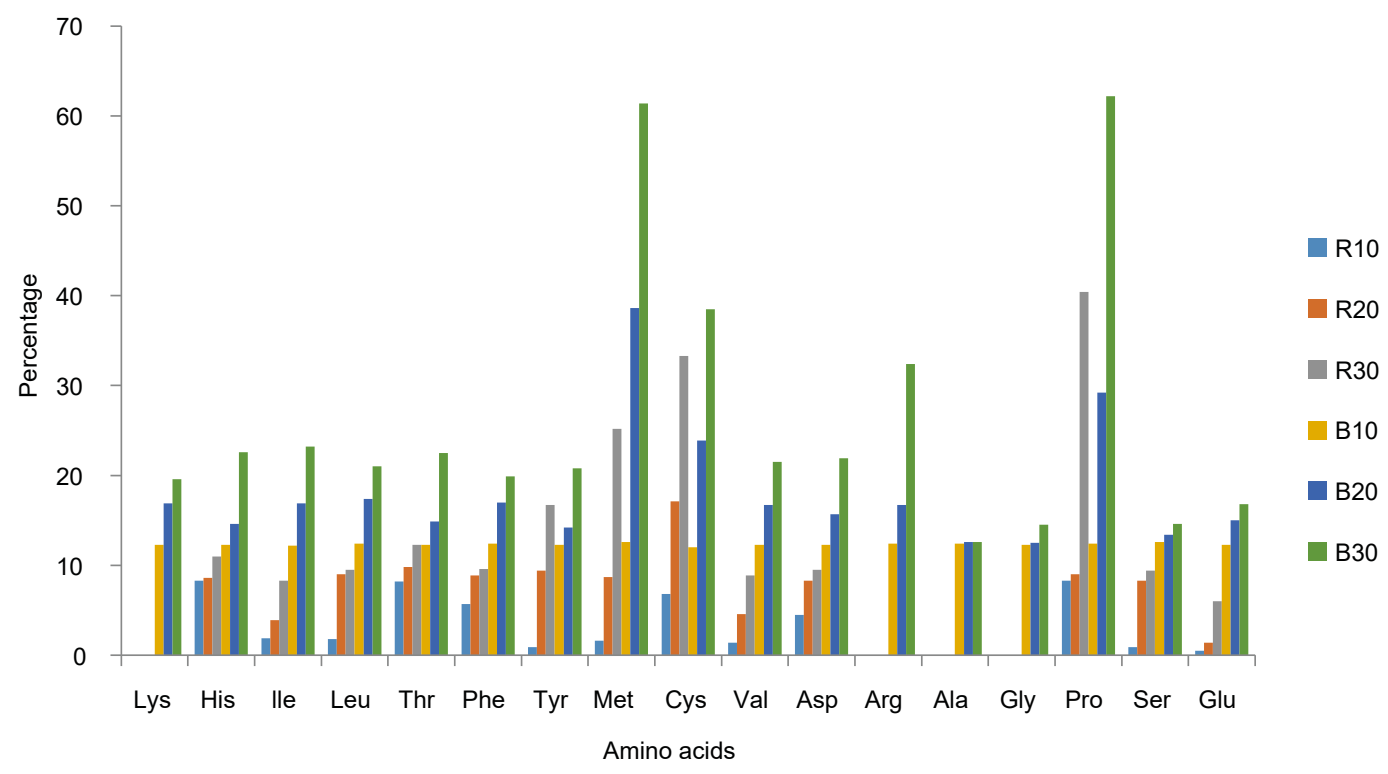

Fig. 1. Effect [\%] of cooking time [min] on the amino acid concentration of Monodora myristica seed flour

The plant food also contains a considerable level of Arginine (4.04-6.42 g/100 g protein) which is a precursor of nitric oxide (NO). Nitric oxide promotes vasodilation in active muscles during exercise, thereby improving strength and recovery (Alvares et al., 2011). According to Falavigna et al. (2012), increasing the dietary intake of BCAAs to $3.57 \%$ improved exercise rate by $37 \%$. Considering the high content of BCAAs and Arginine in the samples, consumption by the sporting community is highly recommended for improved performance. The amino-acid, tryptophan, was either not present in Monodora myristica seed protein or not at a detectable level.

Nitric oxide also plays a major role in male sexual function (Anyalogbu et al., 2015). It is used by the inner lining of blood vessels to signal the surrounding smooth muscle to relax. This leads to vasodilation (blood vessel dilation) and therefore increased blood flow. Consequently, an abundance of nitric oxide can improve circulation and lead to more frequent erections (Thakur et al., 2011). Studies have shown that when supplementing with L-arginine in doses of $5 \mathrm{~g}$ or $2.8 \mathrm{~g}$ daily, men with erectile dysfunction or impotence experienced significant improvements in erectile function (Chen et al., 1999; Zorgniotti and
Lizza, 1994). With the observed level of Arginine (4.04-6.42 g/100 g protein) the plant food holds great potential for application as a dietary intervention to the health condition (erectile dysfunction or impotence).

The high content of lysine in all the samples is also of nutritional significance since the amino acid is usually limited in most cereals and legumes (Onyeike et al., 2005). In addition, lysine together with threonine (2.45-3.16 g/100 g protein) is strictly indispensable among the nine indispensable amino acids, since they are not transaminated and their deamination is irreversible (EFSA, 2012). Incidentally, Monodora myristica is commonly consumed in traditional foods in most parts of Nigeria where cereals and legumes constitute a part of the staple diet. So, it has the potential to augment the daily lysine intake of the consumer. The values for Methionine (0.49-1.27 g/100 g crude protein), though the lowest in all the samples analysed, was comparable with the values $(0.24-1.25 \mathrm{~g} / 100 \mathrm{~g}$ crude protein) reported for most legumes (Alozie et al., 2009).

Crude protein content ranged from 19.92 to $23.32 \%$. The slightly lower value of crude protein in boiled Monodora myristica seeds as compared to the raw and roasted form recorded in this research might 
be as a result of leaching of minerals and soluble proteins into the boiling water. A similar observation was made by Chukwuma et al. (2016) for yellow quality protein maize (QPM) and Adeparusi (2001) for Lima beans (Phaseolus lunatus L.). Moreover, chick beans, 19.4\%, lima beans, $19.8 \%$ (FAO, 1982), kidney beans, $20.9 \%$ and lentils, $22.9 \%$ (Perez-Hidalgo et al., 1997) have a lower amount of protein in comparison with that of Monodora myristica seed flour protein.

\section{The effect of thermal processing on the concentration of amino acids}

The concentration of some of the amino acids investigated was progressively reduced as the cooking time was extended from $10 \mathrm{~min}$ to $30 \mathrm{~min}$ (Fig. 1) with the strongest effect (62.2\%) on Proline (at B30) and weakest $(0.5 \%)$ on Glutamic acid (at R10). Fagbemi (2009) has also reported decreases in most of the amino acids in cashew nuts when processed by drying, fermentation and germination. However, there were also some increases in some of the amino acids in the roasted samples. This may be due to chemical reactions as a result of the processing method employed (Ajibola et al., 2016; Fagbemi, 2009). This phenomenon could likely be due to a reduction of the moisture content during heating which might result in an elevation of the concentration of the flour constituents (El-Hag et al., 2015).

Lysine was increased by $1 \%$ (R10), $2.8 \%$ (R20) and $3.3 \%$ (R30) respectively. Arginine was increased by $1 \%$ (R10), 3.4\% (R20) and 6.9\% (R30) respectively. Furthermore, Alanine was increased by $1.3 \%$ (R10), $2.3 \%$ (R20) and $4.0 \%$ (R30) respectively. Lastly, Glycine was increased by $1.4 \%$ (R10), $2.4 \%$ (R20), and $8.1 \%$ (R30) respectively. Iyenagbe et al. (2017) reported increases of up to $18.85 \%, 33.5 \%$, and $37.5 \%$ in the glycine, tryptophan, and histidine, respectively, for protein isolates of processed conophor nut (Tetracarpidium conophorum) samples. The effect of boiling on the amino acid content of Monodora myristica seeds was more noticeable when the degree of reductions for the individual amino acids was considered. The observed data suggested that M. myristica seed should not be boiled more than 30 minutes to prevent a high leaching effect on the amino acid. Based on the shown effect of cooking on the amino acids, as reflected by the percentage difference between raw and cooked samples (Fig. 1), Alanine was the most stable and Proline and Methionine the most vulnerable amino acids in the samples. Anyalogbu et al. (2015) reported that Tyrosine was the most stable and Serine and Valine the most vulnerable amino acids in cooked Plukenetia conophora (African walnut) seed flours.

The observed decrease in the amino acid level of the sample with increasing cooking time could be accounted for by the leaching of the nutrient into the cooking water. The leaching may have been facilitated by heat which was reported to increase the solubility of nutrients in the processing water (Gernah et al., 2012). The decrease, to some extent may also be attributed to the Maillard reaction (Wei et al., 2009). Muller and Tobin (1980) reported that damage is done by Maillard reactions if the heat treatment causes the reactions to go beyond the deoxy-ketosyl stage. Also, according to Adeyeye (2010), heat treatment at high temperatures causes isomerization of amino acid residues. This involves the deamination reaction and formation of a carbanion which randomly generate L- or D-racemic forms after protonation, and that racemization of the essential amino acid residues of protein reduces its nutritional value to about $50 \%$.

\section{The effect of thermal processing on protein quality parameters}

The total amino acid (TAA) of the raw sample is $83.82 \mathrm{~g} / 100 \mathrm{~g}$ crude protein (Table 3 ). This was close to the values of $97.2,75.8,78.8$ and $90.2 \mathrm{~g} / 100 \mathrm{~g}$ crude protein obtained for soybeans (FAO, 1982), cashew nuts (Aremu et al., 2006a), groundnut seeds (Adeyeye, 2010) and wheat (Khan and Eggum, 1997) respectively (Table 2). Roasting and boiling for up to $30 \mathrm{~min}$ decreased the TAA to between 77.44 and $64.38 \mathrm{~g} / 100 \mathrm{~g}$ crude protein. This range is relatively high compared to the value of 49.95 obtained for Dioscorea rotundata (white yam) (Ogunlade et al., 2011). The total essential amino acid (TEAA) (without His) values of the samples ranged from 24.01 (in B30) to $31.05 \mathrm{~g} / 100 \mathrm{~g}$ crude protein (in raw sample). This compared favourably with the value of $31.7 \mathrm{~g} / 100 \mathrm{~g}$ crude protein reported for wheat (Khan and Eggum, 1997). The percentage ratio of TEAA (with His) to TAA of the samples ranged from 40.1 to $40.9 \%$. This is well above the $39 \%$ considered adequate for ideal protein for infants, $26 \%$ for children 
Agiriga, A. N., Muthulisi, S. (2018). The effect of thermal processing on the protein quality of Monodora myristica (Gaertn.) Dunal seeds. Acta Sci. Pol. Technol. Aliment., 17(4), 321-333. http://dx.doi.org/10.17306/J.AFS.2018.0588

Table 3. Classification of amino acid composition of raw and processed Monodora myristica seed flour, g/100 g crude protein

\begin{tabular}{|c|c|c|c|c|c|c|c|}
\hline Amino acid & Raw & $\mathrm{R} 10$ & $\mathrm{R} 20$ & $\mathrm{R} 30$ & $\mathrm{~B} 10$ & $\mathrm{~B} 20$ & $\mathrm{~B} 30$ \\
\hline Total amino acid (TAA) & 83.82 & 82.04 & 80.19 & 77.44 & 73.48 & 69.84 & 64.38 \\
\hline Total non-essential amino acid (TNEAA) & 49.76 & 48.95 & 48.03 & 46.02 & 43.62 & 41.71 & 38.04 \\
\hline$\%$ TNEAA & 59.4 & 59.7 & 59.9 & 59.4 & 59.4 & 59.7 & 59.1 \\
\hline Total essential amino acid (TEAA) (with histidine) & 34.06 & 33.09 & 32.16 & 31.42 & 29.86 & 28.13 & 26.34 \\
\hline TEAA (without histidine) & 31.05 & 30.33 & 29.41 & 28.74 & 27.22 & 25.56 & 24.01 \\
\hline$\%$ TEAA (with histidine) & 40.6 & 40.3 & 40.1 & 40.6 & 40.6 & 40.3 & 40.9 \\
\hline$\%$ TEAA (without histidine) & 37.0 & 36.97 & 36.68 & 37.1 & 37.04 & 36.60 & 37.3 \\
\hline Total acidic amino acid (TAAA) & 23.76 & 23.27 & 22.80 & 22.01 & 20.83 & 20.14 & 19.30 \\
\hline$\%$ TAAA & 28.35 & 28.36 & 28.43 & 28.42 & 28.35 & 28.84 & 29.98 \\
\hline Total basic amino acid (TBAA) & 15.67 & 15.55 & 15.81 & 16.01 & 13.74 & 13.10 & 11.74 \\
\hline$\%$ TBAA & 18.69 & 18.95 & 19.72 & 20.67 & 18.70 & 18.76 & 18.24 \\
\hline Total sulphur amino acid (TSAA) & 2.44 & 2.34 & 2.13 & 1.73 & 2.14 & 1.67 & 1.21 \\
\hline$\%$ TSAA & 2.91 & 2.85 & 2.66 & 2.23 & 2.91 & 2.91 & 1.88 \\
\hline$\%$ Cys in TSAA & 47.95 & 46.58 & 45.54 & 45.09 & 48.13 & 53.29 & 59.50 \\
\hline Total aromatic amino acid (TArAA) & 7.36 & 7.09 & 6.69 & 6.43 & 6.45 & 6.20 & 5.87 \\
\hline$\%$ TArAA & 8.78 & 8.64 & 8.34 & 8.30 & 8.78 & 8.88 & 9.12 \\
\hline Leu/Ile ratio & 2.14 & 2.15 & 2.03 & 2.11 & 2.14 & 2.13 & 2.21 \\
\hline $\operatorname{Arg} /$ Lys & 0.90 & 0.89 & 0.90 & 0.93 & 0.90 & 0.90 & 0.75 \\
\hline P-PER* & 2.72 & 2.66 & 2.43 & 2.44 & 2.33 & 2.16 & 2.05 \\
\hline $\mathrm{PBV}^{* *}, \%$ & 77.7 & 77.1 & 74.7 & 74.8 & 73.6 & 71.8 & 70.7 \\
\hline
\end{tabular}

*Predicted protein efficiency ratio.

**Predicted biological value.

and $11 \%$ for adults (FAO/WHO/UNU, 1985). The percentage ratio is, however, slightly lower than the $50 \%$ reported for egg (FAO/WHO, 1990). The values are higher than the $19 \%$ obtained for hull free defatted melon "egusi" flour (Colocynths citrullus L.), which is a commonly consumed oil-seed in Sub-Saharan Africa for its protein content (Akobundu et al., 1982), hence, M. myristica seed protein can be regarded as good quality protein. The Arginine/Lysine ratios ( 0.75 to 0.93$)$ obtained in this work were higher than 0.44 reported for casein protein isolate (Mundi and Aluko, 2012). A high ratio of Arginine/Lysine in the diet produces beneficial hypocholesterolemic effects, improving cardiovascular health (Malomo et al., 2014), and also helps in hypertension regulation (Vallabha et al., 2016). Thus, the present results showed that $M$. myristica seed protein might have positive effects on the cardiovascular system.

The Leucine/Isoleucine ratio ranged from 2.03 to 2.21. Some research reports have shown that the Leucine/Isoleucine balance is important in the regulation of the metabolism of tryptophan and niacin, and hence, some disease processes (Belavady et al., 1969; Ghafoorunissa and Narasinga-Roo, 1973). 
The TSAA values (1.21-2.44 g/100 g crude protein) obtained for the samples were lower than $5.8 \mathrm{~g} / 100 \mathrm{~g}$ crude protein recommended for infants $(\mathrm{FAO} / \mathrm{WHO} /$ UNU, 1985). The observed percentage of Cysteine in TSAA ranged from 45.09 to $59.50 \%$. This corroborates the observation of Adeyeye (2004) that most vegetable proteins contained more Cysteine than Methionine. The values compared favourably with the mean value of $60.9 \%$ obtained by Adeyeye (2010) for groundnut seeds. It has been shown that dietary Cysteine has positive effects on mineral absorption, particularly zinc (Mendoza, 2002). The aromatic amino acid (ArAA) contents ranged from 5.87 to $7.36 \mathrm{~g} / 100 \mathrm{~g}$ crude protein and are slightly lower than the minimum value of the range (6.8-11.8 $\mathrm{g} / 100 \mathrm{~g}$ crude protein) suggested for ideal infant protein (FAO/WHO/UNU, 1985).

The Predicted Protein Efficiency Ratio (P-PER) is one of the quality parameters used for protein evaluation (FAO/WHO, 1991). It decreased progressively with increasing cooking time (Table 3) and ranged from 2.05 to 2.72 . These values compare well with the values (2.39-2.60) reported for Conophor protein isolates (Iyenagbe et al., 2017). The P-PER of the plant foods at all levels of processing was higher than 1.50 , below which a protein is taken to be of low or poor quality (Friedman, 1996). Heat treatment of amino acid residues of protein generates a mixture of $\mathrm{L}$ - and
D-racemic forms (Adeyeye, 2010). The presence of D-isomers reduces the digestibility of the protein because peptide bonds involving D-residues are less easily hydrolysed in vivo than those containing only L-residues and thus there is a progressive decrease in P-PER with increased cooking time. Monodora myristica seed protein may be a good dietary vegetable protein supplement.

Biological value (BV) measures protein quality by calculating the nitrogen used for tissue formation divided by the nitrogen absorbed from food (Adeolu et al., 2015). This product is multiplied by 100 and expressed as a percentage of nitrogen utilized. It also provides a measurement of how efficient the body utilizes protein consumed in the diet. Food with a high $\mathrm{BV}$ value correlates to a high supply of the essential amino acids (Oyarekua and Eleyinmi, 2004). Animal sources typically possess a higher biological value than vegetable sources due to the vegetable source's lack of one or more of the essential amino acids. The calculated biological value (BV) in the samples ranged from 70.7 to $77.7 \%$. The value compared favourably with the value of casein $(77 \%)$, soy protein $(74 \%)$ and fairly lower than values in egg $(100 \%)$, beef $(80 \%)$, and whey protein (104\%), and comparably higher than the value reported for wheat gluten (64\%) (Oyarekua and Eleyinmi, 2004). Amino acid scores (Table 4) showed

Table 4. Amino acid score of raw and cooked Monodora myristica seed flour based on the Provisional Amino Acid (Egg) Scoring Pattern (PAAESP)

\begin{tabular}{|c|c|c|c|c|c|c|c|c|}
\hline \multirow{2}{*}{ Amino acid } & \multirow{2}{*}{ PAAESP } & \multicolumn{7}{|c|}{ Amino acid scores, $\%$} \\
\hline & & raw & $\mathrm{R} 10$ & $\mathrm{R} 20$ & R30 & $\mathrm{B} 10$ & B20 & B30 \\
\hline Lys & 5.5 & 121 & 123 & 125 & 126 & 107 & 101 & 98 \\
\hline Thr & 4.0 & 79 & 73 & 71 & 70 & 69 & 67 & 61 \\
\hline Met + Cys & 3.5 & 70 & 67 & 61 & 49 & 61 & 48 & 35 \\
\hline Val & 5.0 & 88 & 86 & 84 & 80 & 77 & 73 & 69 \\
\hline lle & 4.0 & 91 & 89 & 87 & 83 & 80 & 75 & 70 \\
\hline Leu & 7.0 & 111 & 109 & 101 & 100 & 97 & 92 & 88 \\
\hline Phe + Tyr & 6.0 & 123 & 118 & 112 & 107 & 108 & 103 & 98 \\
\hline Try & 1.0 & ND & ND & ND & ND & ND & ND & ND \\
\hline
\end{tabular}

PAAESP - Provisional Amino Acid (Egg) Scoring Pattern. ND - not detected. 
that the protein quality of the sample was decreased by the processing method. Chemical score is a grading in which the quality of a protein can be established by comparing its amino acid content with that of a reference protein, and it recognizes that the value of a protein is determined by the content of its essential amino acids (Onyeike et al., 2005). The content of some essential amino acids was lower than FAO/WHO (1991) recommendations (Table 4). However, raw and processed Monodora myristica seeds were adequate only in Leucine and Phenylalanine + Tyrosine. The result of this study has shown that Methionine + Cysteine are the most or first limiting essential amino acids in all the samples (Table 4). These essential amino acids were also the most limiting in plant foods shown in Table 2. Thus, based on these findings, Monodora myristica may be used as a food supplement for any food material that does not have an adequate amount of essential amino acids. It has been reported that the essential amino acids most often acting in a limiting capacity are Methionine (and Cysteine), Lysine and Tryptophan (Aremu et al., 2006b; Ekeanyanwu, 2013). Tryptophan (Try) could not be determined.

\section{CONCLUSION}

This study has shown that raw and thermally processed Monodora myristica seed kernels contain a substantial amount of the essential amino acids required in food for healthy nutrition and can serve as food supplements for food materials that do not have an adequate amount of essential amino acids based on the FAO/WHO provisional pattern. Although the concentrations of some essential and non-essential amino acids were progressively decreased as the time of heat treatment increased from 10 to $30 \mathrm{~min}$, the high values obtained for the protein quality parameters and essential amino acid scores is indicative that the plant food has the potential to provide high quality protein that could be exploited to enhance protein quality of diets for adults and weaning/complimentary feeding for children. They also exhibited higher levels of biological value and protein efficiency ratios. The high level of Lysine in the plant food at all levels of processing is of nutritional importance since the amino acid is usually limited in most cereals and legumes which incidentally constitute the staple diets of the population that consume plant food in traditional foods. It could therefore be concluded that Monodora mrystica seed kernels could be used as cheap source of protein and essential nutrients in food preparation. With the high content of BCAAs and Arginine observed in the samples, the consumption could enhance performance in sports.

\section{ACKNOWLEDGEMENTS}

The authors are thankful to the College of Agriculture, Engineering and Science, University of KwaZulu-Natal, for financial support.

\section{REFERENCES}

Adeolu, J. A., Ayinde, Y. G., Olatoye, R. A., Adegalu, A. A. (2015). Nutritional and anti-nutritional composition of calabash nutmeg (Monodora myrystica Gaertn.) Dunal seed kernel. J. Chem. Biol. Phys. Sci., 5(4), 3652-3667.

Adeparusi, E. O. (2001). Effect of processing on the nutrients and anti-nutrients of Lima zean (Phaseolus lunatus L.) flour. Food Nahrung, 45(2), 94-96. https:// doi.org/10.1002/1521-3803(20010401)45:2<94::AIDFOOD94>3.0.CO;2-E

Adeyeye, E. I. (2004). The chemical composition of liquid and solid endosperm of ripe coconut. Orient J. Chem., 20(3), 471-476.

Adeyeye, E. I. (2010). Effect of cooking and roasting on the amino acid composition of raw groundnut (Arachis hypogaea) seeds. Acta Sci. Pol. Technol. Aliment., 9(2), 201-216.

Adigun, R. A., Faruq, U. Z., Yauri, U. A. B., Oyeniyi, Y. J. (2015). Analysis of amino and fatty acids composition of Senna alata seed. Am. Chem. Sci. J., 7(1), 1-6. https://doi.org/10.9734/ACSj/2015/16605

Ajibola, C. F., Malomo S. A., Fagbemi T. N., Aluko, R. E. (2016). Polypeptide composition and functional properties of African yam bean seed (Sphenostylis sternocar$p a)$ albumin, globulin and protein concentrate. Food Hydrocoll., 56, 189-200. https://doi.org/10.1016/j. foodhyd.2015.12.013

Akinwunmi, K. F., Oyedapo, O. O. (2013). Evaluation of antioxidant potentials of Monodora myristica (Gaertn.) dunel seeds. Afr. J. Food Sci., 7(9), 317-324. https://doi. org/10.5897/AJFS2013.1020

Akobundu, E. N. T., Cherry J. P., Simmons, J. G. (1982). Chemical, functional, and nutritional properties of egusi (Colocynthis citrullus L.) seed protein products. J. Food 
Sci., 47(3), 829-835. https://doi.org/10.1111/j.13652621.1982.tb12725.x

Alozie, Y., Akpanabiatu, M. I., Eyong, E. U., Umoh, I. B., Alozie, G. (2009). Amino acid composition of Dioscorea dumetorum varieties. Pak. J. Nutr., 8(2), 103-105. https://doi.org/10.3923/pjn.2009.103.105

Alsmeyer, R. H., Cunningham, A. E., Happich, M. L. (1974). Equations to predict PER from amino acid analysis. Food Technol., 28, 34-38.

Alvares, T. S., Meirelles, C. M., Bhambhani, Y. N., Paschoalin, V. M., Gomes, P. S. (2011). L-arginine as a potential ergogenic aid in healthy subjects. Sports Med., 41(3), 233-248.https://doi.org/10.2165/11538590-00000000000000

Anyalogbu, E. A., Onyeike, E. N., Monanu, M. O. (2015). Effect of heat treatment on the amino acid profile of Plukenetia conophora seed kernel flours. Int. J. Biochem. Res. Rev., 7(3), 121-131. https://doi.org/10.9734/ IJBCRR/2015/17018

Aremu, M. O., Olonisakin, A., Bako, D. A., Madu, P. C. (2006a). Compositional studies and physicochemical characteristics of cashew nut (Anarcadium occidentale) flour. Pak. J. Nutr., 5(4), 328-333. https://doi. org/10.3923/pjn.2006.328.333

Aremu, M. O., Olaofe, O., Akintayo, E. T. (2006b). Compositional evaluation of Cowpea (Vigna unguiculeta) and Scarlet runner bean (Phaseolus coccineus) varieties grown in Nigeria. J. Food Agric. Envir., 4(2), 39-43.

Aremu, M. O., Olaofe, O., Basu, S. K., Abdulazeez, G., Acharya, S. N. (2010). Processed cranberry bean (Phaseolus coccineus $\mathrm{L}$.) seed flour for the African diet. Can. J. Plant Sci., 90(5), 719-728. https://doi.org/10.4141/ CJPS09149

Aremu, M. O., Nweze, C. C., Alade, P. (2011). Evaluation of protein and amino acid composition of selected spices grown in the middle belt region of Nigeria. Pak. J. Nutr., 10(10), 991-995. https://doi.org/10.3923/ pjn.2011.991.995

Belavady, B., Gopalan, C., Krishnamurthi, D. (1969). The role of leucine in the pathogenesis of canine black tongue and pellagra. Lancet, 294(7627), 956-957. https://doi.org/10.1016/S0140-6736(69)90610-2

Blomstrand, E., Eliasson, J., Karlsson, H. K., Köhnke, R. (2006). Branched-chain amino acids activate key enzymes in protein synthesis after physical exercise. J. Nutr., 136(1), 269S-273S. https://doi.org/10.1093/ jn/136.1.269S

Burubai, W. E., Amula, P., Daworiye, T., Suwadi, E., Nimame, P. (2009). Proximate composition and some technological properties of African nutmeg (Monodora myristica) seeds. Elect. J. Environ. Agric. Food Chem., 8(5), 396-402.

Chavan, U. D., Mckenzie, D. B., Shahidi, F. (2001). Functional properties of protein isolates from beach pea ( $\mathrm{La}$ thyrus maritimus L.). Food Chem., 74, 177-187. https:// doi.org/10.1016/S0308-8146(01)00123-6

Chen, J., Wollman, Y., Chernichovsky, T. (1999). Effect of oral administration of high-dose nitric oxide donor L-arginine in men with organic erectile dysfunction: results of a double-blind, randomized, placebo-controlled study. BJU Int., 83(3), 269-273.

Chukwuma, O. E., Taiwo, O. O., Boniface, U. V. (2016). Effect of the traditional cooking methods (boiling and roasting) on the nutritional profile of quality protein maize. J. Food Nutr. Sci., 4(2), 34-40. https://doi. org/10.11648/j.jfns.20160402.12

Combaret, L., Dardevet, D., Rieu, I., Pouch, M., Bechet, D., Taillandier, D., ..., Attaix, D. (2005). A leucine-supplemented diet restores the defective postprandial inhibition of proteasome-dependent proteolysis in aged rats' skeletal muscle. J. Phys., 569(2), 489-499. https://doi. org/10.1113/jphysiol.2005.098004

EFSA (2012). Scientific opinion on dietary reference values for protein. EFSA panel on dietetic products, nutrition and allergies (NDA). EFSA J., 10(2), 2557. https://doi. org/10.2903/j.efsa.2012.2557

Ekeanyanwu, C. R., Ogu, I. G., Nwachukwu, U. P. (2010). Biochemical characteristics of the African nutmeg Monodora myristica. Agric. J., 5(5), 303-308. https:// doi.org/10.3923/aj.2010.303.308

Ekeanyanwu, R. C. (2013). Evaluation of the crude protein and amino acid composition of Nigerian Monodora myristica (Ehuru). Pak. J. Nutr., 12(3), 219-223. https:// doi.org/10.3923/pjn.2013.219.223

El-Hag, I. M. N., Ahmed, I. A. M., Eltayeb, M. M., Babiker, E. E. (2015). Effect of processing methods on chemical and amino acid composition of the flours of two winter sorghum cultivars. Innov. Roman. Food Biotechnol., 17, 25-37.

El-Mahdy, A. R., El-Sebaiy, L. A. (1985). Proteolytic activity, amino acid composition and protein quality of germinating fenugreek seeds (Trigonella foenumgraceum L.). Food Chem., 1, 19-23.

Enabulele, S. A., Oboh, F. O. J., Uwadiae, E. O. (2014). Antimicrobial, nutritional and phytochemical properties of Monodora myristica seeds. IOSR J. Pharm. Biol. Sci., 9(4), 01-06. https://doi.org/10.9790/3008-09430106

Fagbemi, T. N. (2009). Effect of processing on chemical composition of cashewnut (Anacardium occidentale). J. Food Sci. Technol., 46(1), 36-40. 
Agiriga, A. N., Muthulisi, S. (2018). The effect of thermal processing on the protein quality of Monodora myristica (Gaertn.) Dunal seeds. Acta Sci. Pol. Technol. Aliment., 17(4), 321-333. http://dx.doi.org/10.17306/J.AFS.2018.0588

Falavigna, G., de Araújo Jr, J. A., Rogero, M. M., de Oliveira Pires, I. S., Graça Pedrosa, R., Martins Jr, E., Alves de Castro, I., Tirapegui, J. (2012). Effects of diets supplemented with branched-chain amino acids on the performance and fatigue mechanisms of rats submitted to prolonged physical exercise. Nutrients, 4(11), 17671780. https://doi.org/10.3390/nu4111767

FAO (1982). Food composition table for use in Africa development of health education and welfare. Rome: Rome Health Science and FAO Nutrition Division.

FAO/WHO (1973). Energy and protein requirements. Technical report series, No. 522. Geneva, Switzerland: FAO/ WHO.

FAO/WHO (1990). Protein quality evaluation. Report of Joint FAO/WHO consultation held in Bethesda. USA, 4-8 December, 1989. Rome: FAO.

FAO/WHO (1991). Protein quality evaluation. Joint Report of FAO/WHO expert consultation, FAO. Food and Nutrition paper 51. Rome, Italy: FAO.

FAO/WHO/UNU (1985). Energy and protein requirements. Report of a Joint FAO/WHO/UNU Export Consultation. WHO Technical Report Series, No. 724. Geneva, Switzerland.

Friedman, M. (1996). Nutritional value of proteins from different food sources: A review. J. Agric. Food Chem., 44(1), 6-29. https://doi.org/10.1021/jf9400167

Gernah, D. I., Ega, B. M., Umoh, U. E. (2012). Effect of boiling time on the quality of Zogale: a snack food produced from peanut (Arachis hypogea) cake and boiled Moringa oleifera leaves. Afr. J. Food Sci., 6(10), 287293. https://doi.org/10.5897/AJFS12.034

Ghafoorunissa, S., Narasinga-Roo, B. S. (1973). Effect of Leucine on enzymes of the trytophan-niacin metabolic pathway in rat liver and kidney. J. Biochem., 134(2), 425-430.

Ismail, A., Hainida, E., Ikram, K. (2004). Effect of cooking practices (boiling and frying) on the protein and amino acids contents of four selected fishes. Nutr. Food Sci., 34(2), 54-59. https://doi.org/10.1108/0034665041 0529005

Iwu, M. M., Igboko, O. A., Onwuchekwa, U. A., Okunji, C. O. (1987). Evaluation of the antihepatotoxic activity of the biflavonoids of Garciana kola seeds. J. Ethnophamrmacol., 21(2), 127-138.

Iyenagbe, D. O., Malomo, S. A., Idowu, A. O., Badejo, A. A., Fagbemi, T. N. (2017). Effects of thermal processing on the nutritional and functional properties of defatted conophor nut (Tetracarpidium conophorum) flour and protein isolates. Food Sci. Nutr., 5(6), 1170-1178. https://doi.org/10.1002/fsn3.508
Khan, M. A., Eggum, B. O. (1997). The nutritional quality of some Pakistani wheat varieties. J. Sci. Food Agric., 30, 779-784.

Malomo, S. A., He, R., Aluko, R. E. (2014). Structural and functional properties of hemp seed protein products. J. Food Sci., 79(8), C1512-C1521. https://doi.org/https:// doi.org/10.1111/1750-3841.12537

Mbah, B. O., Eme, P. E., Ogbusu, O. F. (2012). Effect of cooking methods (boiling and roasting) on nutrients and anti-nutrients content of Moringa oleifera seeds. Pak. J. Nutr., 11(3), 211-215. https://doi.org/10.3923/ pjn.2012.211.215

Mendoza, C. (2002). Effect of genetically modified low phytic acid plants on mineral absorption. Int. J. Food Sci. Tech., 37(7), 759-767. https://doi. org/10.1046/j.1365-2621.2002.00624.x

Muller, H. G., Tobin, G. (1980). Nutrition and food processing. London: Croom Helm.

Mundi, S., Aluko, R. E. (2012). Physicochemical and functional properties of kidney bean albumin and globulin protein fractions. Food Res. Int., 48(1), 299-306. https:// doi.org/10.1016/j.foodres.2012.04.006

Nuray, E., Ozkan, O., Arif, S. (2010). Effect of frying, grilling, and steaming on amino acid composition of marine fishes. J. Med. Food, 13(6), 1504-1509. https://doi. org/10.1089/jmf.2009.0203

Ogunlade, I., Olaifa, O., Adeniran, O. A., Ogunlade, A. O. (2011). Effect of domestic processing on the amino acid profile of Dioscorea rotundata (White yam). Afr. J. Food Sci., 5(1), 36-39. https://doi.org/10.5897/AJFS

Ojiako, O. A., Igwe, C. U., Agha, N. C., Ogbuji, C. A., Onwuliri, V. A. (2010). Protein and amino acid compositions of Sphenostylis stenocarpa, Sesamum indicum, Monodora myristica and Afzelia Africana seeds from Nigeria. Pak. J. Nutr., 9(4), 368-372. https://doi. org/10.3923/pjn.2010.368.372

Olaofe, O., Adeyemi, F. O., Adediran, G. O. (1994). Amino acid and mineral composition and functional properties of oil seeds. J. Agric. Food Chem., 42(4), 879-881.

Olaofe, O., Okiribiti, B. Y., Aremu, M. O. (2008). Chemical evaluation of the nutritive value of smooth luffa ( $L u f$ fa cylindrica) seed's kernel. Elect. J. Env. Agric Food Chem., 7(10), 3444-3452.

Onyeike, E. N., Ayalogu, E. O., Okaraonye, C. C. (2005). Nutritive value of the larvae of raphia palm beetles (Oryctes rhinoceros) and weevil (Rhyncophorus pheonicis). J. Sci. Food Agric., 85(11), 1822-1828. https://doi. org/10.1002/jsfa.2054

Oser, B. L. (1959). An integrated essential amino acid index for predicting the biological value of protein. In: A. A. 
Albanese (Ed.), Protein and amino acid nutrition. New York: Academic Press.

Oyarekua, M. A., Eleyinmi, A. F. (2004). Comparative evaluation of the nutritional quality of corn, sorghum and millet ogi prepared by modified traditional technique. Food Agric. Environ., 2(2), 94-99.

Perez-Hidalgo, M., Guerra-Hernandez, E., Garcia-Villanova, B. (1997). Determination of insoluble dietary fiber compounds: cellulose, hemicellulose and lignin in legumes. Ars Pharm., 38(4), 357-364.

Pisarikova, B., Kracmar, S., Herzig, I. (2005). Amino acid contents and biological value of protein in various amaranth species. Czech J. Anim. Sci., 50(4), 169-174.

Severin, S., Wen-Shui, X. (2006). Nutritional evaluation of caseins and whey proteins and their hydrolysates from Promatex. J. Zhejiang Univ. Sci. B., 7(2), 90-98. https:// doi.org/10.1631/jzus.2006.B0090

Shimomura, Y., Murakani, T., Nakai, N., Nagasaki, M., Harris, R. A. (2004). Exercise promotes BCAA catabolism: effects of BCAA supplementation on skeletal muscle during exercise. J. Nutr., 134 (6 Suppl.), 1583S-1587S. https://doi.org/10.1093/jn/134.6.1583S

Sreerama, Y. N., Neelam, D. A., Sashikala, V. B., Pratape, V. M. (2010). Distribution of nutrients and anti-nutrients in milled fractions of chickpea and horse gram: Seed coat phenolics and their distinct modes of enzyme inhibition. J. Agric. Food Chem., 58(7), 4322-4330. https://doi. org/10.1021/jf903101k
Thakur, M., Thompson, D., Connellan, P., Deseo, M. A., Morris, C., Dixit, V. K. (2011). Improvement of penile erection, sperm count and seminal fructose levels in vivo and nitric oxide release in vitro by ayurvedic herbs. Andrologia, 43(4), 273-277. https://doi.org/10.1111/ j.1439-0272.2010.01068.x

Tuleum, C. D., Patrick, J. P., Tiamiyu, L. O. (2009). Evaluation of raw and boiled velvet beans (Mucunautilis) as feed ingredient for broiler chickens. Pak. J. Nutr., 8(5), 601-606. https://doi.org/10.3923/pjn.2009.601.606

Udeala, O. K. (2000). Preliminary evaluation of dike fat, a new tablet lubricant. J. Pharm. Pharmac., 32, 6-9.

Vallabha, V. S., Tapal, A., Sukhdeo, S. V., Govindaraju, K., Tiku, P. K. (2016). Effect of arginine:lysine ratio in free amino acid and protein on L-NAME induced hypertension in hypercholesterolemic Wistar rats. RSC Advances, 6, 73388-73398. https://doi.org/10.1039/ C6RA13632J

Wei, Z. Y., Wang, J. S., Cao, Z. Y., Zhang, Z. Y., Li, X. J. (2009). Effect of high temperature high humidity on contents of protein, amino acids and sugars in wheat grains. J. Chin. Cereals Oils Assoc., 24(9), 5-11.

Weiss, E. A. (2002). Spice crops (pp. 102-103). Oxon: CABI Publ.

Zorgniotti, A. W., Lizza, E. F. (1994). Effect of large doses of the nitric oxide precursor larginine, on erectile dysfunction. Inter. J. Impoten. Res., 6, 33-35. 